\title{
Fear of China: Economic and Political Challenge in the 21st Century: A Pacific Society, Weapons, Roots and Trends
}

\author{
Niccolo Caldararo ${ }^{1}$ \\ ${ }^{1}$ Dept. of Anthropology, San Francisco State University, San Francisco, United States \\ Correspondence: Niccolo Caldararo, Ph.D., Dept. of Anthropology, San Francisco State University, San Francisco, \\ United States.
}

Received: October 25, 2017

Accepted: November 23, 2017 Online Published: November 28, 2017

doi:10.20849/ajsss.v2i4.227

URL: https://doi.org/10.20849/ajsss.v2i4.227

\begin{abstract}
While the world has been distracted since the American war in Vietnam and the Soviet and western adventures in Afghanistan, as well as a rising tide of rebellion directed against symbols of the west by Islamic fundamentalists, a curious contest has appeared on two fronts: Russia and China. At the same time the west is distracted by populist movements whose theme is focused on immigrants from former colonial nations or non-whites in a context, as in America, where aboriginal peoples have been slaughtered and marginalized. The specific nature of this conflict is economic in general form, yet political in rhetoric, especially from western sources. From the Ukraine to the Pacific a kind of "Phoney War" has crept along in starts and stops with overtures of friendship interrupted with threats of violence and minor acts of aggression. Investigation of some of the underlying factors in the East illuminate potential trends for the future. At the same time a new revitalization movement is reshaping the Anglo-American west, one that challenges the role of China in trade and policy.
\end{abstract}

Keywords: China, colonialism, post-colonial transition, conflict, popular, movements, revolution, weapons, pacific society

\section{Introduction}

Fear of China is growing in the west, and especially in America. Concern arises from both China's economic achievements and the potential of its political and military capabilities (Economist, 2007, 2016; Mizokami, 2014; Stokes, 2016; Kynge, et al., 2017). Pankj Mishra's new book, Age of Anger has produced a number of critical responses (e.g., de Bellaigne, 2017), most of which have focused on his conclusions concerning present world problems as consequences of western colonialism. But more positive views of China's history are beginning to appear to reassess a constructive future as in Robert Bickers' (2017). But we should be specific about the nature of this "fear," it is psychological fear of personal danger, or loss, or is it a concern that is based on economic competition, or is it a manifestation of the unfamiliar or strange differences shown by differences in physical type as when Europeans where first encountered by native peoples a great distances from Europe?

We can address the idea of fear from descriptions in the media. A Google search or other web browser produces more than 126 million hits. Sampling these items one can break them down into several general categories: 1 . Beyond the economic challenge mentioned above in an individual sense or 2. The idea of military competition both in Asia and the world (as in the new port or naval base in Sri Lanka) or 3. Reference to a more psychological fear evoked in people by more articles in the media and images of China's greater prominence in economic power expressed globally, as in banking, mergers and acquisitions or foreign direct investment, Forex and immigration that can affect local businesses and global finance? 4. There is China's economic and political activities as a cultural "form" that requires linking as "soft power", is this more "Chinese" in Chinese government or Chinese in immigrants, as in African investment, media and business?

Does one find in comments on fear, from an American perspective, fear from Africans as different from European colonialism? That is, Chinese, as government representatives or simply as Chinese looking individuals (e.g., Chinese-American citizens) or other Chinese speaking foreign nationals. Or 8.is the psychological aspect of fear more immediate as in fear of the artificial islands being produced nearer China proper and seen as military threats by people in, say, the Philippines? That is, a fear of loss of national rights, territory or identity (rights, for example, of fishermen in certain zones), and finally, 9. Do we mean Chinese, as Chinese mainland, The People's Republic of China, overseas Chinese, as in scholars in South America or those in America or Europe or those Chinese from 
Taiwan, as the Republic of China?

Rather than listing millions of entries from the web search or those on data bases like jstor, I have compiled a sample list with sources as representing the data in categories in Table 1.

Table 1. Fear of China in the $21^{\text {st }}$ century

Table 1.1. Economic Fears

Rise of China not good for global economy (Time, 2011): increased cost of goods and services, competition for resources, increased western debt

Allen \& Unwin drop publication of a book critical of China for fear of retaliation Financial Times, Nov. 13, 2017

Survey of economic fears of China in global content of companies published in Journal of Asian Economics, "Fear of China," v. 17, n, 2, April 2006: 226-240 by Eichengreen and Tong.

Table 1.2. Sinophobia: roots in $20^{\text {th }}$ century, Communism, Mao political threat

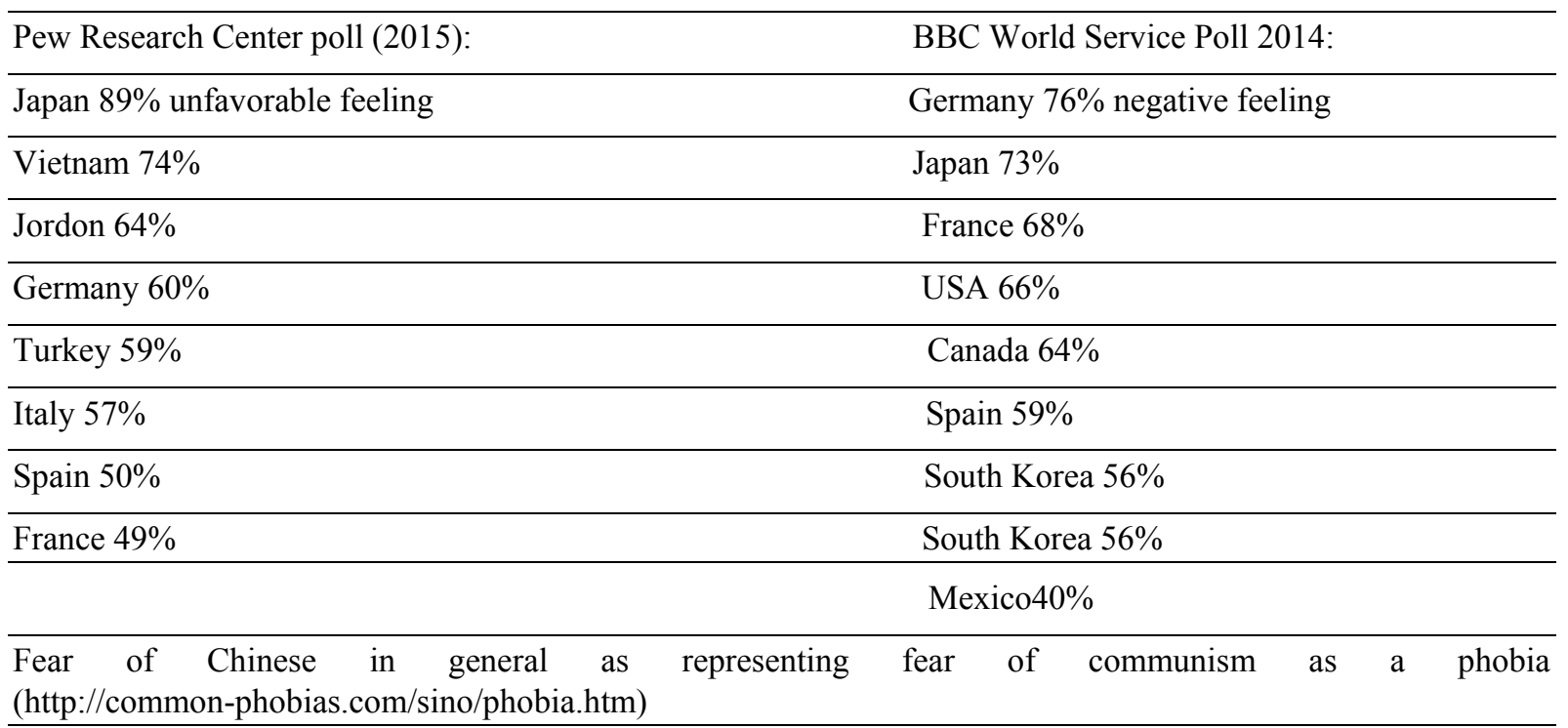

Table 1.3. Political Fear

Hong Kong fear of loss of freedom "anthem" issue The Guardian (8/32/17)

Hong Kong artists fear loss of freedom (CNN, 6/30/17)

Hong Kong demonstration turns violent over anxiety of China \& loss of freedom (Time Magazine 11/6/16) CNN Hong Kong booksellers and tycoon arrested over new publication law (6/28/17)

Fear in North Korea of China isolating Kim reported by Newsweek Oct. 2, 2017 in link to Russian firm TransTeleKom

It is strange that politicians and philosophers as well a social scientists should argue that the massacres, tortures, slavery and cultural genocide of the post-1492 holocaust against non-European people should be considered a thing of the past and irrelevant to the future as some like Niall Ferguson have. Some have even argued that colonialism was a positive experience for non-western people (Ferguson, 2003, 2012). Contrasting the upsurge of anti-government and anti-western anger and violence (e.g., Arab Spring) to that of American citizens of the Tea Party or Trump supporters, creates a momentous contradiction.

While Tea Party members and Trump supporters called for taking their country back, the fact that the original inhabitants had experienced actually losing their country, an event perpetrated by the ancestors of those now 
complaining, was lost to them. The nature of protest today is not more intense or violent, but is irrationally devoid of history and proportion. Where American and European warplanes in Libya and Russian in Syria, created millions of refugees to flood Europe creating a humanitarian and political crisis, the populist votes against immigrants are made in nations whose warplanes or munitions sales created the crisis.

In the immediate post-colonial period many social scientists, including anthropologists, for example Lucy Mair (1969) and Melville Herskovits (1959), attempted to describe the potential transformation of colonial societies to new societies based on the cultural patterns and pre-colonial social framework. One of Mair's earliest works (1928) was on the survival of minorities during the process of nationalism and nation building following the First World War. This also was the concern of a number of African-American anthropologists like Drake (1960) who focused on the nature of authority and the construction of institutions.

One need not review the extermination of Native Americans, or the mass enslavement of African people and torture often exemplified by those imposed on Central Africa by King Leopold of Belgium (Hochschild, 1999). There has been plenty of reason for non-European peoples to rise up and overthrow colonialism. But what then? The writings of Franz Fanon $(1959 ; 1961)$ characterized the problem of post-colonial nations, born as they were within the straight-jacket boundaries of the colonial masters either at the Berlin Conference of 1884-5 (for much of Africa) or before. How could a society reform itself from the physical and psychological savagery of colonialism? One sees attempts to cleanse people in the film Mad Masters from West Africa, a process of satire and parody is applied to the colonial culture and mother country through an preexisting spiritual framework, in this case, the Hauka (Stoller, 1984). It is often argued that most colonialized people are not revolting, do not support Boko Haram, etc. (Obeidallah, 2014) nor did they support the Mau-Mau (Chandler \& Beckett, 1994), but the same argument was made in 1776 about American rebels. Commager and Morris (1958) reproduce and cite a number of documents critical of the American revolutionaries.

\section{The Experience of Extermination}

It is obvious that Native American cultures experienced an organized, brutal and unrelenting process of obliteration by European colonists. Not only were great cities stripped of their indigenous stone architecture, but all elements of dance, song, plastic arts and literature were outlawed, systematically destroyed and deemed evil products of the devil (Tozzer, 1941; de la Vega, 1609; Vaillant, 1944; Caldararo, 1994). While the physical evidence of their cultures was reduced to rubble, the minds of generations were carefully controlled in missionary schools and by continuous European attack on Native life and ritual (Wallace and Steen, 1970; McDade and Huff-Corzine, 2009). We can see the origins of the present forms of resistance in the past, as the movements of jihad in Subsahara Africa have been characterized as being a response to the expansion of the transatlantic slave trade into the hilad as-sudan since the $18^{\text {th }}$ century (Curtin, 1995).

The same process was repeated, from the conquest of Grenada by the Spanish in 1492, to the Canary Islands, the Pacific, and Africa. The attempt to destroy Chinese culture took place, perhaps too late, and was resisted too stubbornly and was too far away at a time when European powers were in critical conflict. Peffer (1930) attempted a comprehensive analysis of how western military and economic attack affected China's government and institutions as well as its culture, though it suffered from a western-oriented progressivism. China is depicted in western histories as weak, unable to respond militarily or industrially to the challenge of Europe, this seems clear from Cipolla's (1965) survey. As Cipolla (1970) notes, ideas of weakness are usually couched in terms of decline, economic or political decline are often relative, societies are conceived of a slow death, but often it is a case of relative growth.

In the history of Italian city states or $17^{\text {th }}$ century Spain, decline was not only relative, but some experienced renewal but at rates much slower than other states. If we project this beginning about 5,500 years ago and start with the Egyptian kingdom and then Empire (3100 B.C.E. to about 664 B.C.E. or about 2,300 years), we find a decline from the Old Kingdom to the New with a number of periods of decline and renewal (Wilson, 1951; Andreu, 1997). Greece is more difficult, we cannot begin with Sparta and the Hellenic League as our sources, Thucydides and Xenophon, describe it as voluntary and neither a state nor an empire. Athens is usually depicted in western histories as the font of democracy and philosophy, but we find both originating elsewhere. Anaxagoras is often credited with bringing philosophy to Athens from Ionian Turkey, his home in Clazomenae and later the rustic Athenians put him on trial for impiety, so much for tolerance and free discourse (Filonik, 2013). The Athenian Delian League began as a voluntary group led by Athens but grew into a coercive imperial entity, but using either the Athenian Empire and Alexander the Great's maximum extent at this death (323 B.C.E.) as the apogee and the decline in power of the empires of his generals versus Rome (to the conquest of Ptolemic Egypt by the Romans in 31 B.C.E) we can establish a period (470-31 B.C.E. or 439 years) of rise to power and 
decline. Some historians have considered Rome an extension of Greece's Hellenistic culture and civilization, just as some have, including an ancient writer, Herodotus, the Greek civilization was an outgrowth of Egyptian via the Minoans and Mycenaeans (Butzer, 1976). However, Rome seems clearly a separate social entity as does Greece. For Rome we would begin after the Battle of Allia and the sack of Rome in 390 B.C.E. to 363 C.E. with the death of Julian Augustus and the surrender of both his army and territory, including major cities. The empire did not recover, either economically or militarily (Cipolla, 1970; Rostovtzeff, 1926) and so we can fix a time of start and nadir between these dates, or almost 1,000 years.

Should we compare the products of social development in the length of stable internal relations and maximum extent of empire and economy we could make no parallels, as definitions of "stability" are varied. So leaving off internal conditions and focusing on extent and expression of power, we might come to some general relations. So, if we compare empires and their regional as well as "world" influence, both economically and politically and their population, we might produce a chart as in Chart 1 below. Here the vertical scale is a relative value of influence and extent of power. Rome rose to its greatest power after the Second Punic War, the Mongols had a great empire but it was short-lived like Alexander's. For the Mongols, beginning about 1206 with Genghis Khan to its fracture with Kublai's death in 1294, while some coherence continued under the Chagatai Khanate until the mid- $14^{\text {th }}$ century, we find, at best, a total of 150 years. England fell to no successful invasions after 1066 C.E. (though major invasions continued as in that of King Magnus Barefoot of Norway ending in 1103 C.E.) but only succeeded in achieving empire after the defeat of the Dutch invasion of England in 1667 (Coox, 1949) and achieved its world power after the defeat of Napoleon. English world power ended in WWI and its collapsed colonial empire shortly after. America rose to world power in WWI and reached its apogee after the fall of the Soviet Union and seems to be ebbing in the failures in Iraq, Afghanistan and the challenge of ISIS and its like. On such a scale, China would be seen as appearing several times in "world" influence in Asia, yet today we must add a new period of influence as it begins to assert itself anew.

$$
\mid
$$

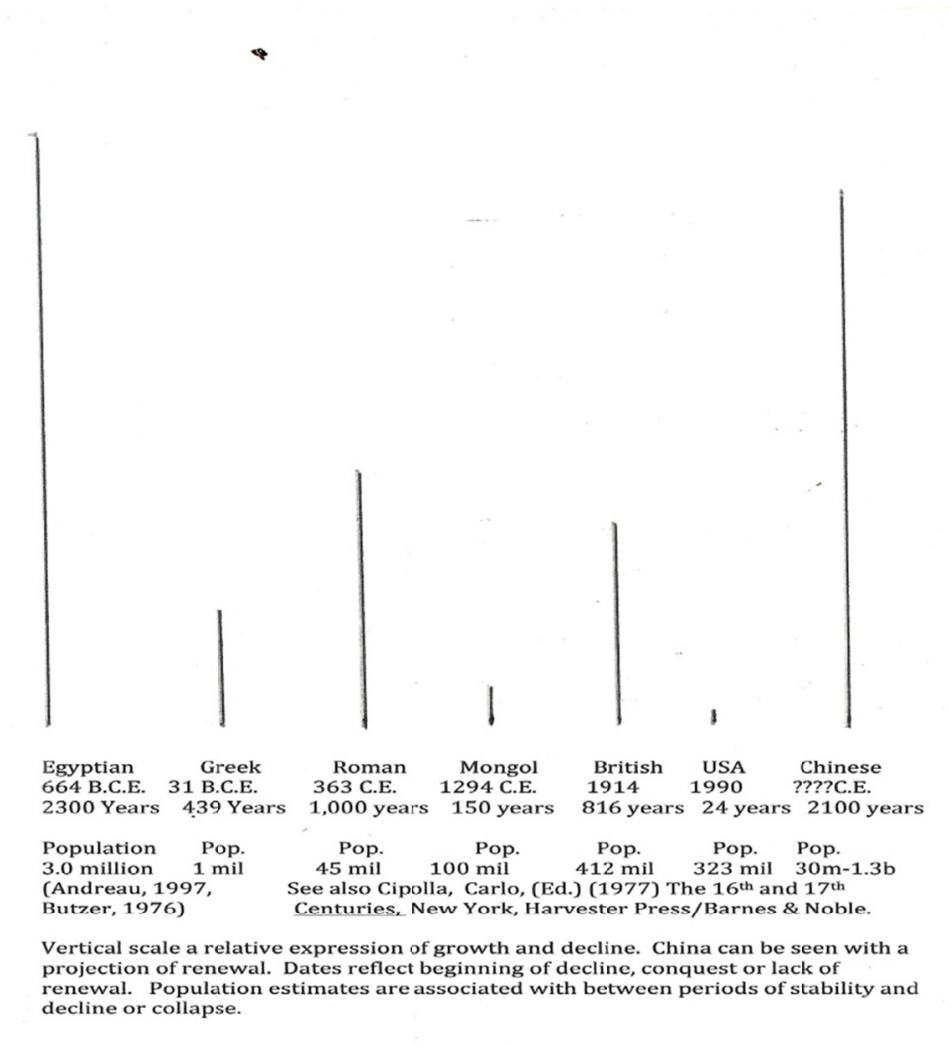

Figure 1

In Cipolla's (1970) terms China had fallen behind in relative value, but as her rivals have also experienced recent 
deceleration in growth and influence, China now can be seen as in a period of revitalization, in many ways like those it has experienced in the past (Reischauer and Fairbank, 1958). Looking over the information in the chart one might notice that population is contrasted with estimated zenith of power and length of ascendance. As Berreman (1978) noted we focus on size of a political entity, its economic productivity, how its institutions function, scale is significant but the time scale is not. In fact, the stability over time is often considered a feature of decay or decline. Scale, Berreman (1978) reports often includes not just density of population, but interaction density of individuals. Demographers, historians and economists have been divided on the benefits of population, its density and organization since before Malthus (1830) proposed his theory on population (Hutchinson, 1967).

Chinese renewal of the dynasties has been a central feature of Chinese culture history. We might consider a similar pattern, from Ancient Egypt to Crete and Greece, to Rome, to England and then the USA. That, however, would require historians to mark the origin of Western Civilization not with Greece, but in Africa and Egypt, as both Diop (1974) and Firmin (1885) have argued. While China has experienced continuity over the dynasties with invasions and rebellions as major forms of disruption, in Egypt, after the Old Kingdom was disorganized and reorganized by invaders it also experienced renewal and the later invasions and absorptions of foreigners as well as internal rebellion and reordering (Wilson, 1951).

Assessments of growth can be measured in economic or political terms, but other elements can be significant, as today where China has tremendous economic growth, but its military and cultural regard is much less than the USA that might be considered to be declining economically but still preeminent militarily and culturally. Cultural variations can be important and lead to revitalization as Europe experienced after the $15^{\text {th }}$ century. In this the medieval disorder of extensive violence, personal and political, could be seen as a sign of decline.

However, the means of contending for influence can be achieved through many avenues other than just economic or military strength. "Soft Power" is one and in this arena China has been making new efforts. Past communication to "peoples' movements of liberation" or to overseas Chinese populations through art and theater have been complemented with an array of successful major movie productions in recent years. In a recent article, David Shambaugh (2015) quotes President Xi Jinping as saying: "We should increase China's soft power, give a good Chinese narrative, and better communicate China's messages to the world." Shambaugh analyzes the various methods that are being undertaken in this effort, both in the area of broadcast TV, radio, internet and print media. The appeal has a certain familiarity to it in comparison to US media in the past 6 decades since WWII, especially in such outlets as Radio Free Asia (Welsh, 2014). Where China has often had the role of a repressive regime or evil aggressor in Western media, new Chinese films like Wolf Warrior 2 by Director Wu Jing, depicts a former elite People's Liberation Army soldier who defends Chinese citizens and local factory workers against corrupt and brutal American-led mercenaries. This follows US films like Red Dawn where the villains were Chinese as in the Manchurian Candidate. Today those evil ones are more likely to be cast as North Korean in Western films. Whether China has an opportunity to balance its own image abroad versus America's varied one (Nye, 1990) will be seen in its developments and investments abroad.

China has been pictured by Europeans during much of its history as a stable and organized political entity, especially given its depiction in the works of travelers like Marco Polo (1298-9). But another interpretation can come from views made at the time of initial conflict in the $17^{\text {th }}$ century where China's failure to modernize its weaponry made little sense to Europeans (Mayers, 1869-1870). Nieuhoff (1699) reports that China presented a society with few arms, "nobody is suffered to wear arms within a city, nor the soldiers nor commanders nor the learned, unless they are upon the march and going to the wars. Neither are they suffered to have arms in their houses or to ride armed otherwise than with a dagger to defend themselves against highwaymen." This certainly contrasts with a Europe where arms commonly appeared as a part of every man's wear who could afford them and is related to the monopoly of force and pacification of society (Spierenburg, 2008; 2012). It also brings up the goal of society, is it to create a peaceful and productive population, or a violent and disruptive one? So was the violence of Europe a symptom of decline or transformation?

Considering this the social violence in the Roman Republic accelerated after the Punic Wars leading to the Civil Wars and the massacres and destruction of institutions that had fostered Roman power in the view of many historians like Polybius. This violence produced the military dictatorship and continued civil war over succession. When do we draw a line to determine the beginning of decline? The death of Marius or the recall of Sylla? The failed agrarian program or the growing inequality? Or the Civil War?

\section{The Turn of Asia}

Carlo Caldarola and Raymond Pong (Pong \& Caldarola, 1982) detailed the repeated attacks on China's cities, lands and most importantly, its people after the crushing defeat China suffered in the Opium War of 1840-1842. 
There had been many previous attempts to encroach on Chinese territory as adventurers like Pinto (1569) describe in the $16^{\text {th }}$ century and these increased in number decade by decade. Some few Asian countries were aware and preparing for the onslaught, as in the case of Japan whose embassies in the $16^{\text {th }}$ century allowed her leaders to learn the horror of European colonialism first hand in New Spain and of the nature of Europe, even visiting the Pope (Caldararo, 2016). She then closed her borders and prepared by a process of managed culture change in the indigenous introduction of new technologies facilitated by Dutch merchants (Caldararo, 2003; 2016).

It cannot be denied that the Chinese empire advanced by conquest, but it is abundantly clear that a comparison of the modern history of China and that of Europe during and after the voyages of discovery (1400-1850) demonstrate a very different pattern. Chinese voyages were aimed at trade, European characterized by conquest (Reischauer, and Fairbank, 1958). It is likely that the central difference can be found in the lack of a totalizing ideology among the Chinese, where Christianity, not only denied the value of other religions but banned their existence as being fabrications of the devil (Caldararo, 1994, 2002).

Perhaps the most forgotten assault on China was the British invasion of Tibet in 1903. Tibet was then under Chinese administration, the native kings having been eliminated by the Mongols centuries before (Hoffman, 1961). The excuse for the British invasion was the supposed interest in Tibet by the Russians and fear the Dalai Lama was negotiating with the Tsar.

Tibet was the only Himalayan country not in British hands in 1900. The Dalai Lama had refused to meet with the British and had sent a Russian Agvan Dorjiyev to ask the Russians for protection in 1900. In 1903 the Russians gave the British assurances they had no interest in Tibet. That led the British to cross the border, the Dalai Lama fled to China and the British army captured Lhasa. The massacre of the native Tibetans by the British under General James Macdonald and Francis Younghusband had a terrifying effect on the Tibetans, especially given the ease with which Chinese troops and weapons had been defeated by modern rifles and the Maxim machine guns (Allen, 2004; Bell, 1992).

A Japanese Buddhist monk, Ekai Kawaguchi (1909), recorded an eyewitness account of the society of indigenous Tibet before the British conquest as well as the impact of British rule on Tibetans from his two trips one before the invasion and one after (Berry, 1990; 2005). Reassessments of the value of the colonial enterprise as anything but an exploitative process and self-promoting nationalism are beginning to appear given both the truth of violence and repression of culture at the hands of missionary and "civilizing" agendas (Wilson, 2016; Miller, 1974), though somewhat less strident than that of Mishra's (2016).

\section{China in the Aftermath of Defeat}

European claims on China increased pressure on the national government. Pong and Caldarola (1982) describe how China was beset by the military powers of Europe as well as the economic, political and religious. Three groups of missionaries swarmed into European controlled territories: fundamentalist, conservative and liberal Christian evangelists. Gunboat diplomacy and unequal treaties left Chinese officials at the mercy of these people seen by most Chinese intellectuals as the handmaiden of foreign aggression (Neill, 1966; Wu, 1930).

Missionary schools were financed from abroad by either church organizations or governments and were of a better quality than state-run Chinese schools. "Better quality" in many reports relates to specific goals of the operators, usually Europeans, and varied from learning Christian dogma to teaching service skills for Chinese youth as workers for Europeans. They were independent of any Chinese control and were found to produce little in the way of actual education, but mainly were organs to propagate Christianity as well as justify European intervention in China (Miller, 1974). The dismemberment of China was facilitated by the eagerness of religious groups to protect their investments in converts, an example being the Holy See's agreement with the Japanese resulting in the Catholics' work being respected by the Japanese authorities in occupied territories and the Holy See's strict observance of neutrality to Japanese intervention (Wei, 1970).

Missionary schools did not teach Chinese children as Chinese, but as American or English children, learning English, American or European history, the result was a generation of Chinese "deflowered" of their culture (Peffer, 1930). In this context one can see how responses today to the teaching of "western values" might be negative (Anderlini, 2015). The process of colonization of conquered peoples is like that of domestication of animals and represents the organization seen in parallel form in the superorganism of eusocial animals (Gowdy \& Krall, 2016). Its failure or success depends on the ability of conqueror institutions to integrate and assimilate subject peoples into systems of subordination and the nature of the hegemony of the symbols of that system (Gramsci, 1971). 


\section{The Problem of Postcolonial Society}

Recently Gideon Rachman reviewed several books in the Financial Times (2017). His review informs us as to how little has changed in western scholarship regarding China in the past two decades.

Rachman begins with Graham Allison's "Thucydides Trap" theory (Allison, 2017). If we examine the theory, however, it immediately falls into ruins. Allison believes that the war between Sparta and Athens was caused by Athens' fear of the rise of Sparta. This would come as a surprise for most people from reading Thucydides' history and that of Herodotus, Aristotle and Xenophon. In these histories (most Western historians, except a precious few like Toynbee, ignore the Spartan historians though most of their writings like those of Sosibius are lost or simply fragments of a few passages) we find Athens building a political and economic empire. Their raiding the coast of Asian Minor and desecration of the temples of the cities they sacked, caused the Persians to desire revenge. That behavior can be seen as the reason for the invasion of Greece under Darius and Xerxes, and the defense of Greece by the Spartans (and other Greeks) at Thermopylae in 480 B.C.E.

It was such disregard for honor and humanity that led to the Peloponnesian War (431-404 B.C.E.). Athens built her empire on ruthless trading policies and conquest that threatened all of the independent Greek cities. Sparta became the leader of the free cities against Athenian hubris and growing arrogance. In the end, Athenian greed and corruption resulted in her defeat. Most European historians have found in the Athenians a reflection of their own history, as imperialists, mercantilists and slave owners.

To bring this into a contemporary context one can see the parallel, but it is the obverse of the Greek situation, the US and the European powers have conquered and dominated the globe for 4 centuries. Their power was broken in two great "World Wars" perhaps a better terms would be civil wars (or one might say tribal wars given Fried's 1975 perspective) in the 20th century where Europeans and the Americans wasted their treasure and people in years of massacre. Now in the shadow of that disaster the west fears those it oppressed. That is only natural, but it is not a consequence of what Dr. Allison's theory predicts. His is an entirely eurocentric view of the world.

The views of Howard French (2017), Michael Green (2017), Tom Miller (2017) and Bernard Cole (2016) are all in the same vein. The lack of historical context is remarkable, how can one talk of China's response to the west without noting the colonial war Europe brought to the world? Here Green is the only stand out. One must recall that trade up to the mid-19th century with China had drained Europe, and especially England of its silver and was causing a serious economic crisis. China bought little from Europe, like the past 3 decades, and yet Europe was buying Chinese wares and becoming a debtor. The solution in the 19th century was first an attempt to swamp China with opium (Jones, et al., 2010; Deming, 2011) and then when the Chinese blocked this, European armed forces invaded, resulting in the defeat of China and a near century of looting the nation. In 1903 England invaded Tibet on a similar pretext based on the idea the Russians were going to do it anyway, as noted above.

Rachman's (2017) comments on Japan follow a similar path of inevitability which Allison's theory predicts, though masks the actions of the USA in Asia, as his theory distorts and overlooks those of Athen's in Asia Minor over 2,600 years ago. While Japan had closed her borders to the west after the arrival of Europeans like Fernao Mendes Pinto. Her government sent two Embassies to Europe from Japan in the early 16th century. But Japan's authorities' attempt to deal with the threat was not as China had, and isolation (Caldararo, 2003; 2016) saved her from the contamination of her people by contact with western values. When forced to open to the west by the United States of America (Beasley, 2002), the Japanese immediately saw their only survival in becoming like the Europeans and Americans and to avoid being like those non-European peoples who were colonized and enslaved. Seeing how Europeans treated non-Europeans was central to this transformation (Caldararo, 2003).

Japan's rise took place at the time of China's defeat and dismemberment at the hands of Europeans. Japan in the late 19th century was unconquered or colonized, a rare position for a non-European people. They embarked on a program of establishing themselves as equal to European powers then contending for China's resources. Japan in 1900 was the only non-European power in the world and its existence was only recognized after the Russo-Japanese War of 1904-5. As Japan attempted to seize colonies for itself to model its nation as a European colonizer it was threatened by the western nations who saw Japan as a threat to its colonies. Here the Anglo-Japanese Treaty of 1902 was a product of this fear, yet the demonstration by the Japanese in their destruction of the Russian navy in the East and its armies, showed that they could act as a powerful force in a European manner.

After World War I Japan offered that all world powers give up their colonies and a policy of respect for all peoples be accepted by the victors at Versailles (Caldararo, 2003). Rejected, Japan went on to its earlier program of mimicking European colonial interventions and a decade later, led to the Mukden Incident in Manchuria (Duus and Hall, 1989). This led to the protest of the Allied powers and the 5 Powers Treaty which was ostensibly 
about disarmament (even as the conference was taking place the USA was building 10 major warships) but really forced on Japan military limits to protect European spheres of influence (Marriot, 2005; Howarth, 1983). Not satisfied and wanting to preserve western control the USA called another meeting, the 9 Power Treaty, to force Japan out of China. Billed as a means to protect China which was already divided up, there was no change except Japan exited Shangtung Province and Siberia.

If the west wants to avoid conflict with China then there should be an effort to avoid the last consequence of western debt with her. In 1839 the west could have worked on a constructive resolution to the silver drain to China and Britain's mounting liabilities there. Instead Britain chooses war. Today we find China (and Germany) accused of currency manipulation or hoarding when the real problem is a lack of productivity in the west. While we hear so much about American creativity, we see a crisis of the economy that threatens world peace.

\section{Conclusion: Cleansing the Aroma of Humiliation}

Just as the people of Africa's Niger produced the Hauka to expel the psychological damage created by the humiliation of colonial racism, post -colonial societies will likely to continue to reverberate in rebellions of all kinds, from processes of reindigenation to the Red Guards and ISIS (Caldararo, 2015). One cannot expect normality from those who have been traumatized, to see no wounds from the distortion of their past and erasure of their culture and religion. It is amazing to read books on the Cultural Revolution in China (Dikotter, 2016) that present the turbulent history of post-WWII China as if the colonial period and the violence of its history never existed. It would be like a French writer in 1710 writing critically of Cromwell's revolution by making the Royalist past a golden era.

The Arab spring of 2011 was seen by many as being the beginning of a renovation of Islam and a merging of Arab culture with European modernity, yet it was little more than a public demonstration of the ghosts of European colonialism and the authoritarian regimes created after the end of colonialism and born in its ashes. We can expect more contradictions in the world until the borders of colonialism have been remeasured by peoples reinventing authentic culture and societies somehow cleansed of the barriers of European colonial culture and its perspective we call modernity (Clammer, 2001). That is not to say that China has ignored the role of religion or culture in extending and protecting its borders. As Waley-Cohen (1998) has noted, in her analysis of the Qing and the challenges they faced from the Zunghars, Mongols, Islam and Bon in the west. Religion and culture were tools and threats to be managed, encouraged and weakened in turn to maintain power and order. How China's leaders use their history in facing the new challenges of the $21^{\text {st }}$ century facing a "popularist" or revitalization (Wallace, 1956) movement in the Anglo-American west will be a momentous task. Western revitalization movements, as during the Reformation and in the colonial enterprise (especially in America) and recently in Germany after WWII, have been violent and aggressive. This new phase is likely to follow a similar path.

\section{References}

Allen, Charles. (2004). Duel in the Snows. London, John Murray.

Allison, Graham. (2017). Destined for War: Can America and China Escape Thucydides' Trap?. New York, Houghton Mifflin Harcourt.

Anderlini, \& Jamil. (January 31, 2015). Beijing blocks 'western values' in classrooms. Financial Times.

Andreu, Guillemette. (1997). Egypt in the Age of the Pyramids Ithaca: Cornell University Press.

Beasley, W.B. (2002). The Perry Mission to Japan, 1853-4. London, Psychology Press, Routledge.

Bell, Charles. ( 1992). Tibet Past and Present. CUP Motilal Banarsidass Publ.

Bellaigue, Christopher De. (7 January, 2017). In the Danger Zone. The Financial Times.

Berreman, Gerald D. (June 1978). Scale and social relations. Current Anthropology, 19(2), 225-245. https://doi.org/10.1086/202073

Berry, Scott. (1989). A Stranger in Tibet: The Adventures of a Wandering Zen Monk. Kodansha International, Tokyo. Also published as A Stranger in Tibet: Adventures of a Zen Monk, Harper Collins (1990).

Berry, Scott. (2005). The Rising Sun in the Land of Snows: Japanese Involvement in Tibet in the Early 20th Century. Ardash Books, New Delhi.

Bickers, Robert, (2017). Out of China: How the Chinese Ended the Era of Western Domination. London, Allen Lane.

Butzer, Karl. (1976). Early Hydraulic Civilization. University of Chicago Press.

Caldararo, N. (2003). The Concept of the Sustainable Economy and the Promise of Japan's Transformation. 
Anthropological Quarterly, 76(3), 463-478. https://doi.org/10.1353/anq.2003.0036

Caldararo, N. (2015). Local Resistance in the Era of Capitalist Globalization: Clash of Cultures in the 21st Century. The IUP Journal of International Relations, IX(3), 7-22.

Caldararo, N. (1994). The lost libraries of the Americas. Library History, 10, 9-18. https://doi.org/10.1179/lib.1994.10.1.9

Caldararo, N. (October 30, 2002). The origin and nature of fundamentalism in society. Human Nature Review, 2 , 469-482. http://human-nature.com/nibbs/02/history.html

Caldararo, N. (2016). The Origins of the Nation-State in Japan: Destruction of Militant Buddhism and Western Contact of the 16th and 17th Centuries: Implications for the Concept of the State. American Studies Eurasian Perspective, 1(2), 87-98. https://doi.org/10.15340/2147349812964

Chandler, David G., Beckett \& Ian Frederick William. (1994). The Oxford Illustrated History of the British Army. Oxford, Oxford University Press.

Cipolla, Carlo. (1965). Guns, Sails and Empires: Techological Innovation and European Expansion (p. 1400-1700). New York, Barnes \& Noble.

Cipolla, Carlo. Introduction, in Carlo Cipolla (ed.). (1970). The Economic Decline of Empires. London, Meuthen.

Cipolla C.M. (1976). Before the Industrial Revolution: European Societyand Economy (2 ${ }^{\text {nd }}$ ed. P.1000-1700). N.Y., W.W. Norton.

Cipolla, C.M. (ed.). (1977) The Sinteenth and Seventeeth Centuries, The Fontana Economic History of Europe. 2, Harvester Press/Barnes \& Noble.

Clammer, John. (2001). Japan and Its Others: Globalization Differences, and the Critique of Modernity. Japanese Society Series, Melbourne, Trans Pacific Press.

Cole, Bernard. (2016). China's Quest for Great Power. Annapolis, Naval Institute Press.

Commager, Henry Steele, \& Morris, Richard B. (eds.). (1958). The Spirit of 'Seventy-Six, The Story of the American Revolution as Told by Participants. New York, The Bobbs-Merrill C.

Coox, Alvin D. (1949 winter). The Dutch invasion of England: 1667. Military Affairs, 13(4), 223-233. https://doi.org/10.2307/1982741

Curtain, Philip. (1995). The West African Coast in the Era of the Slave Trade. in P.Curtain, S. Feierman, I. Thompson, \& J. Vansina (Eds.) African History From Earlist Times to Independence. London, Longman.

De La Vega, Garcilaso. (1971). The Royal Commentaries of the Inca. Written in 1609, Discus Book (ed.).

Deming, Sarah. (2011). The Economic Importance of Indian Opium and Trade with China on Britain's Economy: 1843-1890. Economics Working Papers, \#25. Whitman College.

Dikotter, Frank. (2016) The Cultural Revolution: A People's History, 1962-1976. New York, Bloomsbury.

Diop, Cheikh Anta. (1974). The African Origin of Civilization. Lawrence Hill Books.

Drake, St. Clair. (1960). Traditional authority and social action in former British West Africa. Human Organization, 19(3), 150-8. https://doi.org/10.17730/humo.19.3.m02536016n07u38t

Duus, Peter, \& Hall, John-Whitney. (1989). The Cambridge History of Japan: The twentieth century. P.294. Cambridge, Cambridge University Press. https://doi.org/10.1017/CHOL9780521223577

Editorial. (May 17, 2007). America's fear of China. The Economist.

Editorial. (June 12, 2016). Why Sino-America relations are likely to become stormier. The Economist.

Fanon, Franz. (1959). A Dying Colonialism. (1965 translation by Haakon Chevalier: New York, Grove Press)

Fanon, Franz. (1961). The Wretched of the Earth. (1963 translation by Constance Farrington: New York: Grove Weidenfeld).

Ferguson, Niall. (2003). Empire: How Britain Made the Modern World. London: Allen Lane.

Ferguson, Niall. (2012). Civilization: The West and the Rest. New York, Penguin Books.

Filonik, Jakub. (2013). Athenian impiety trials: a reappraisal. Dike (16), 26-33.

Firmin, Antenor. (1885). The Equality of the Human Races. Trans. By Asselin Charles. Urbana, University of Illinois Press (ed.), (2002).

French, Howard. (2017). Everything Under the Heavens: How the Past Helps Shape China's Push for Global 
Power. New York, Alfred Knopf.

Fried, Morton. (1975). The Notion of Tribe. Cummings Publishing Co.

Frier, Bruce W. (1982). Roman Life Expectancy: Ulpian's Evidence. Harvard Studies in Classical Philology 86. https://doi.org/10.2307/311195

Gowdy, John, \& Krall, Lisi. (2016). Economic origins of ultrasociality. Behavior and Brain Sci., 39, 1-60. https://doi.org/10.1017/S0140525X1500059X

Gramsci, Antonio. (1971). Selections from the Prison Notebooks of Antonio Gramsci. New York, International Publishers.

Green, Michael. (2017). By More Than Providence: Grand Strategy and American Power in the Asia Pacific Since 1783 (A Nancy Bernkopf Tucker and Warren I. Cohen Book on American-East Asian Relations). New York, Columbia University Press. https://doi.org/10.7312/gree18042

Herskovits, Melville, \& Bascom, William (eds). (1959). Continuity and Change in African Culture. Chicago, University of Chicago Press.

Hochchild, Adam. (1999). King Leopold's Ghost: A Story of Greed, Terror and Heroism in Colonial Africa. Houghton Mifflin.

Hoffman, Helmut. (1961). Religions of Tibet. New Work, MacMillian.

Howarth, Stephen. (1983). Morning GloryL History of the Imperial Japanese Navy. London, Hamish Hamilton.

Huan, Ma., \& Ying-Yai Sheng-Lan. (1433). The Overall Survey of the Ocean's Shores. Chengjun Feng \& J. V. G. Mills (eds) in Dec 2, 1970, CUP Archive.

Hutchinson, E.P. (1976). The Population Debate: The Development of Conflicting Theories up to 1900. Houghton - Mifflin, Co.

Jones, Geoffrey, Köll, Elisabeth, \& Gendron, Alexis. (2010). Opium and Entrepreneurship in the Nineteenth-Century. HBS No. 9-805-010. Boston: Harvard Business School Publishing.

Kawaguchi, Ekai. (1909). Three Years in Tibet. The Theosophical Office, Adyar, Madras.

Kynge, James, Kazmin, Amy, \& Bokhari, Farhan. (13 January 2017). How China rules the waves. The Financial Times.

Mair, Lucy. (1928). The protection of minorities; The working and scope of the minorities treaties under the League of Nations. London, Christophers.

Mair, Lucy. (1969). Anthropology and social change. Athlone.

Malthus, Thomas. (1960). On Population, (published anonymously in 1824 in the Encyclopedia Britannica, revised and shortened in 1830). New York, New American Library of World Literature.

Marriott, Leo. (2005). Treaty Cruisers: The First International Warship Building Competition. London, Barnsley: Pen \& Sword.

May, Timothy. (2012). The Mongol Conquests in World History. Reaktion Books, distributed by University of Chicago Press.

Mayers, W.F. (1869-1870). On the introduction and use of gunpowder and firearms among the Chinese. $\underline{\text { J. North }}$ China Branch of the Royal Asiatic Society, 73-104.

McDade, Jeffrey R. \& Huff-Corzine, Lin. (2009). The Birth of the American Indian Manual Labor Boarding School: Social Control Through Culture Destruction, 1820-1850. Lewiston, Edwin Mellen Press.

Miller, Stuart C. (1974). Ends and means: missionary justification of force in nineteenth century China. in J.K. Fairbank(ed.), The Missionary Enterprise in China and America, Cambridge, Harvard University Press. https://doi.org/10.4159/harvard.9780674333505.c14

Miller, Tom. (2017). China's Asian Dream: Empire Building along the New Silk Road. London, Zed Books.

Mishra, Pankaj. (2016). Age of Anger: A History of the Present. London, Allen Lane.

Mizokami, Kyle. (May 7, 2014). Five Chinese weapons of war America should be concerned about. The National Interest.

Neill, Stephen. (1966). Colonialism and Christian Missions. New York, McGraw-Hill.

Nieuhoff, J. (1673). An Embassy to China. Amsterdam, Jacob van Meurs, 1668 London, White-Friers.

Nye, Joseph. (1990). Bound to Lead: The Changing Nature of American Power. New York, Basic Books. 
Obeidallah, Dean. (1930). Boko Haram terrorist are not Islamists. The Daily Beast. Retrieved from http://www.thedailybeast.com/articles/2014/05/12/the-boko-haram-terrorists-are-not-islamic.html on May 12,2014

Peffer, Nathaniel. (1930). China: The Collapse of a Civilization. New York, John Day.

Pinto, Fernao., Mendes. Peregrinacam (Travels). (1989). Edited and translated by Rebecca D. Catz. Chicago: University of Chicago Press (Originally written after 1569, published posthumously in 1614).

Polo, Marco. (1958). The Travels of Marco Polo, or De Mirabilibus Mundi as told to Rustichello da Pisa, 1298-9. Trans. By Latham, Ronald, London: Penguin Classics,.

Pong, Raymond, \& Caldarola, Carlo. (1982). China: Religion in a Revolutionary Society. in Carlo Caldarola (ed.) Religions and Societies: Asia and the Middle East. (P. 551-578). Berlin, Mouton Publishers.

Rachman, Gideon. (April 1, 2017). The Struggle for Asia. Financial Times.

Reischauer, E., \& Fairbank, J., K. (1960). East Asia, the Great Tradition, 1. Boston: Houghton.

Rostovtzeff, M. (1926)._Social and Economic History of the Roman Empire._Oxford, Clarendon Press.

Shambaugh, David. (2015). China's Soft Power push. Foreign Affairs, July/August. Retrieved from https://www.foreignaffairs.com/articles/china/2015-06-16/china-s-soft-power-push

Spierenburg, Pieter. (2008). A History of Murder: Personal Violence in Europe from the Middle Ages to the Present. Cambridge, Polity.

Spierenburg, Pieter. (2012). Violence and Punishment: Civilizing the Body Through Time. Cambridge, Polity.

Stokes, Bruce. (January 29, 2016). American Fear of China Weighs on U.S. Election. Pew Research Center.

Stoller, Paul. (1984, Summer). Horrific Comedy: cultural resistance and the Hauka Movement in Niger. Ethos, 12(2), 165-188. https://doi.org/10.1525/eth.1984.12.2.02a00050

Tozzer, Alfred M. (ed.). (1941). Landa's Relacion de las Cosas de Yucatan. Papers of the Peabody Museum of Archaeology and Ethnology, Harvard University, v. 18, Cambridge. (originally written by Landa about the year 1566).

Vaillant, G.C. (1944). Aztecs of Mexico. London, Pelican.

Waley-Cohn, Joanna. (Jun. 1998). Religion, war and empire-building in Eighteenth Century China. The International History Review, 20(2), 336-352. https://doi.org/10.1080/07075332.1998.9640827

Wallace, A.F.C., \& Steen, Sheila C. (1970). The Death and Rebirth of the Seneca: The History and Culture of the Great Iroquois Nation, Their Destruction and Demoralization, and Their Cultural Revival at the Hands of the Indian Visionary Handsome Lake. New York, Knopf.

Wallace, A.F.C. (April 1956). Revitalization movements. Amer. Anthro, 58(2), 264-281. https://doi.org/10.1525/aa.1956.58.2.02a00040

Wei, Louis. (1970). China and the Vatican. China Notes, 8(4).

Welch, David. (2014). Propaganda, power and persuasion from World War I to Wikileaks. London New York: I.B. Tauris.

Wilson, John A. (1951). The Culture of Ancient Egypt. Chicago, U. Chicago Press.

Wilson, Jon. (2016). India Conquered: Britain's Raj and the Chaos of Empire. New York, Simon \& Schuster.

Wu, Chao-kwang. (1930). The International Aspect of the Missionary Movement in China. Baltimore, John Hopkins Press.

\section{Copyrights}

Copyright for this article is retained by the author(s), with first publication rights granted to the journal.

This is an open-access article distributed under the terms and conditions of the Creative Commons Attribution license (http://creativecommons.org/licenses/by/4.0/). 